\title{
Perbedaan Konsentrasi Kombinasi Starter Tiga Bakteri terhadap Total Bakteri Asam Laktat, Nilai pH, dan Total Asam Tertitrasi Yogurt
}

\section{Combination Starters of Three Bacteria Against Total Lactic Acid Bacteria, pH Value, and Total Titrable Acidity Yoghurt}

\author{
D. R. Pratama, S. Melia, dan E. Purwati* \\ Fakultas Peternakan, Universitas Andalas, Padang, 25163 - Indonesia \\ *Corresponding E-mail: purwati17@yahoo.co.id \\ (Diterima: 1 Agustus 2020; Disetujui: 2 Oktober 2020)
}

\begin{abstract}
ABSTRAK
Tujuan penelitian ini adalah menganalisis pengaruh penggunaan kombinasi 3 Bakteri Asam Laktat untuk starter yogurt dengan penggunaan bakteri Lactobacillus fermentum, Streptococcus termophillus dan Pediococcus acidilactici pada penambahan konsentrasi yang berbeda terhadap Total Bakteri Asam Laktat, Nilai $\mathrm{pH}$, dan Total Asam Tertitrasi Yogurt. Inokulasi kultur bakteri asam laktat dalam pembuatan starter sebanyak $5 \%$ dari volume susu kemudian diinkubasi pada suhu $37^{\circ} \mathrm{C}$ selama 16 jam dan dilanjutkan pembuatan Yogurt beserta perlakuan. Metode dalam penelitian ini ialah metode eksperimental dengan rancangan acak lengkap 3 perlakuan dan 6 ulangan. Perlakuannya adalah penambahan persentase konsentrasi Starter yogurt A1 (3\%), A2 (5\%), dan A3 (7\%). Analisis data menggunakan analisis ragam apabila ada pengaruh maka dilanjutkan dengan uji Duncan. Hasil penelitian menunjukkan bahwa perbedaan penambahan persentase konsentrasi Starter yogurt berpengaruh $(\mathrm{P}<0,05)$ terhadap Total Bakteri Asam Laktat, Nilai $\mathrm{pH}$, dan Total Asam Tertitrasi. Pada pengujian perlakuan perbedaan konsentrasi penggunaan starter terbaik terdapat pada konsentrasi $5 \%$ dengan hasil pengujian total koloni bakteri asam laktat $78,83 \times 10^{8} \mathrm{cfu} / \mathrm{ml}$, nilai $\mathrm{pH} 4,68$ dan Total Asam Tertitrasi 0,750.
\end{abstract}

Kata kunci: bakteri asam laktat, Pediococcus acidilactici, starter, yogurt

\section{ABSTRACT}

This research aims to analyze using a combination of 3 Lactic Acid Bacteria for yogurt starters using Lactobacillus fermentum, Streptococcus termophillus, and Pediococcus acidilactici on the addition of different concentrations on Total Lactic Acid Bacteria, $p H$ Value, and Total Acidic Acid Yoghurt. Inoculation of lactic acid bacteria in the manufacture of a starter as much as 5\% of the volume of milk and then incubated at room temperature for 16 hours and continued making Yogurt along with the treatment. The method was used experimentally with a completely randomized design, three treatments, and six replications. The treatment was the addition of the percentage yogurt starter concentration A1 (3\%), A2 $(5 \%)$, and $A 3(7 \%)$. Data analysis used analysis of variance if there was an influence, then proceed with the Duncan test. The results showed the difference in the percentage of yogurt starter concentration affected $(P<0.05)$ on the total lactic acid bacteria, $\mathrm{pH}$ value, and the total titrated acid. In the treatment test, the difference in using the best starter is at a concentration of $5 \%$. The results of testing the total colony of lactic acid bacteria $78.83 \times 108 \mathrm{CFU} / \mathrm{ml}$, a pH value of 4.68, and a total titrated acid of 0.750 .

Keywords: lactic acid bacteria, Pediococcus acidilactici, starter, Yogurt 


\section{PENDAHULUAN}

Bakteri asam laktat (BAL) ialah kelompok bakteri yang dapat mengubah laktosa menjadi asam laktat. BAL merupakan potensi sumber kimiawi yang baik dengan kepentingan teknologi dan bersifat fungsional, dengan adanya mikroorganisme yang sangat penting dengan status aman Generally Regard As Safe (GRAS). Bakteri asam laktat merupakan bakteri yang pada umumnya digunakan dalam fermentasi susu (Yildiz, 2010).

Peran BAL ini penting terutama dalam menekan pertumbuhan bakteri yang tidak disukai yaitu penyebab kebusukan dan bakteri patogen (Pramono et al., 2009). BAL akan menghasilkan asam laktat dan asam asetat yang merupakan antimikroba yang penting dan mempunyai aktivitas tinggi (Suskovic et al., 2010) serta mempunyai penghambatan yang luas terhadap bakteri gram negatif (Khikmah, 2015). Mekanisme BAL untuk melindungi makanan dari bakteri patogen penyebab kebusukan adalah dengan memproduksi asam organik, hidrogen peroksida, diasetil komponen anti jamur seperti seperti asam laktat atau asam fenulaktik dan bakteriosin (Messens and De Vugst, 2002).

Salah satu jenis produk olahan susu yang memanfaatkan peran bakteri asam laktat dalam proses fermentasinya ialah yogurt. Yogurt adalah produk yang diperoleh dari susu yang telah dipasteurisasi, kemudian difermentasikan dengan bakteri tertentu sampai diperoleh keasaman, bau dan rasa yang khas, dengan atau tanpa penambahan bahan lain (Surajudin et al., 2006). Yogurt merupakan susu yang difermentasi dengan menggunakan biakan campuran mikroba umumnya Lactobacillus bulgaricus dan Streptococcus thermophilus, sehingga menghasilkan konsistensi menyerupai puding. Pada penelitian terdahulu dari Purwati et al., (2018) menggunakan subtitusi bakteri asam laktat Lactobacillus fermentum L23 dan Streptococcus thermophilus, menghasilkan konsenterasi terbaik pemberian starter pada konsenterasi $5 \%$.

Bakteri Lactobacillus fermentum L23 yang digunakan dalam penelitian ini diisolasi dari susu kerbau yang berasal dari kabupaten Agam, Sumatera Barat dan telah diidentifikasi secara molekuler (Melia et al., 2017). Lactobacillus fermentum termasuk kedalam bakteri asam laktat dimana kerjanya juga membantu proses fermentasi laktosa yang terdapat di dalam susu. Sedangkan untuk bakteri ketiga dalam penelitian ini menggunakan Pediococcus acidilactici PB22 yang diisolasi dari bekasam asal sumatera selatan (Melia et al., 2019). Peran Pediococcus acidilactici diharapkan dapat membantu aktivitas proteolitik yang biasa dilakukan Lactobacillus bulgaricus pada suhu optimum $45^{\circ} \mathrm{C}$, dengan memproduksi peptida penstimulasi dan asam amino yang dapat dipakai oleh Streptococcus thermophilus suhu optimum $42^{\circ} \mathrm{C}$.

Sehubungan dengan itu, potensi peningkatkan kualitas starter yogurt dengan penggunaan 3 kultur bakteri ini memiliki potensi dalam proses pembuatan produk yogurt. Dimana dengan penggunaan kombinasi 3 kultur bakteri asam laktat (BAL) diharapkan dapat meningkatkan kualitas starter dan produk yogurt. Berdasarkan potensi tersebut, penelitian ini bertujuan menganalisis pengaruh penggunaan kombinasi 3 Bakteri Asam Laktat untuk starter yogurt dengan penggunaan bakteri Lactobacillus fermentum, Streptococcus termophillus, dan Pediococcus acidilactici pada konsentrasi starter yang berbeda terhadap Total Bakteri Asam Laktat, Nilai pH, dan Total Asam Tertitrasi Yogurt.

\section{METODE}

Penelitian ini dilakukan di Laboratorium Teknologi Hasil Ternak, Fakultas Peternakan Universitas Andalas Padang pada bulan November 2019. Materi yang digunakan dalam penelitian ini adalah susu sapi segar yang diperoleh dari peternakan yang ada dikota Padang. 
JPI Vol. 22 (3): 339-345

Tabel 1. Kultur Starter Yogurt

\begin{tabular}{lcccc}
\hline Jenis Bakteri & Katalase & $\begin{array}{c}\text { Pewarnaan } \\
\text { Gram }\end{array}$ & $\begin{array}{c}\text { Karakterisitik } \\
\text { Morfologi }\end{array}$ & (CFU/mL) \\
\hline Streptococcus thermophilus & $(-)$ negative & Gram positif & Coccus (bulat) & $76 \times 10^{8}$ \\
Lactobacillus fermentum & $(-)$ negative & Gram positif & Bacil (batang) & $92 \times 10^{8}$ \\
Pediococcus acidilactici & $(-)$ negative & Gram positif & Coccus (bulat) & $58 \times 10^{8}$ \\
\hline
\end{tabular}

Metode yang digunakan dalam penelitian ini ialah metode eksperimental rancangan acak lengkap dengan 3 perlakuan dan 6 ulangan. Perlakuannya ialah A1 (penambahan persentase konsentrasi Starter yogurt 3\%), A2 (penambahan persentase konsentrasi Starter yogurt 5\%) dan A3 (penambahan persentase konsentrasi Starter yogurt 7\%).

\section{Prosedur Starter Yogurt}

Dalam penelitian ini dilakukan pembuatan starter berdasarkan modifikasi cara Purwati, Melia, Juliyarsi, Rossi, dan Purwanto (2018) paten no. SID201804980.

\section{Prosedur Pembuatan Yogurt}

Pembuatan yogurt Menurut Legowo (2009) dengan modifikasi, sebagai berikut: Melakukan proses pasteurisasi susu pada suhu $65^{\circ} \mathrm{C}$ selama 30 menit; Menurunkan suhu susu pasteurisasi hingga $43^{\circ} \mathrm{C}$; Menginokulasikan starter yogurt (kombinasi bakteri Lactobacillus fermentum, Streptococcus termophillus, dan Pediococcus acidilactici PB22) berdasarkan perlakuan persentase starter A1 (3\%), A2 (5\%), dan A3 (7\%); Melanjutkan proses inkubasi pada suhu $37^{\circ} \mathrm{C}$ selama $12 \mathrm{jam}$, dan Produk yogurt sebagai sampel pengujian telah siap untuk diuji.

\section{Pengujian Parameter}

Beberapa peubah yang diuji dalam penelitian ini meliputi Total koloni bakteri asam laktat (Purwati et al., 2005), Nilai pH (Apriantono et al., 2000), dan Total Asam Tertitrasi (Aritonang, 2009) yogurt.

\section{Analisis Data}

Analisis data yang digunakan dalam penelitian ini dilakukan menurut prosedur Steel dan Torrie (1993). Pengolahan datahasil pengujian menggunakan IBM SPSS statistics 23 dan apabila terdapat pengaruh dari perlakuan maka dilanjutkan dengan uji Duncan Multiple Range Test (DMRT).

\section{HASIL DAN PEMBAHASAN}

\section{Pengujian Kultur Starter Bakteri}

Kultur starter merupakan bakteri awal sebelum digunakan dalam pembuatan produk fermentasi. Jumlah populasi kultur starter berada dikisaran $58 \times 10^{8}-92 \times 10^{8}$ $\mathrm{CFU} / \mathrm{mL}$, populasi awal kultur ini sudah mencukupi untuk digunakan sebagai starter yogurt (Tabel 1). Menurut Siswanti (2002) kultur starter pada pembuatan susu fermentasi berada pada kirsaran $10^{8}-10^{9} \mathrm{CFU} / \mathrm{mL}$. Hal ini sesuai dengan Dicagno et al. (2008) menyatakan Streptococcus thermophilus mempunyai karakter berbentuk bulat atau kokus dan termasuk dalam kelompok gram positif. Bakteri umum yang digunakan dalam pembutan yogurt menghasilkan baik asam maupun $\mathrm{CO}_{2}$. Asam dan $\mathrm{CO}_{2}$ yang dihasilkan tersebut kemudian merangsang pertumbuhan dari Lactobacillus bulgaricus dan Pediococcus acidilactici. Lactobacillus fermentum adalah bakteri yang berbentuk batang merupakan kelompok bakteri gram positif. Secara kimia, bakteri ini akan mendegradasi karbohidrat pada media pertumbuhannya menjadi glukosa kemudian asam laktat yang dapat menstimulir pertumbuhan Streptococcus thermophilus. Di sisi lain, untuk aktivitas proteolitik dari Lactobacillus bulgaricus dapat digantikan oleh peran Pediococcus acidilactici pada suhu optimum $45^{\circ} \mathrm{C}$, dengan memproduksi peptida penstimulasi dan asam amino yang dapat dipakai oleh Streptococcus thermophilus suhu 
JPI Vol. 22 (3): 339-345

Tabel 2. Karakteristik susu segar dan starter yogurt

\begin{tabular}{lcccc}
\hline Peubah & Susu Segar & Starter & $\begin{array}{c}\text { Referensi } \\
\text { Susu* }\end{array}$ & $\begin{array}{c}\text { Referensi } \\
\text { Starter ** }\end{array}$ \\
\hline pH & 0,64 & 4,55 & - & $3-5$ \\
TAT (\%) & 0,14 & 0,85 & - & $1-2$ \\
Protein (\%) & 3,53 & 3,67 & 3,50 & - \\
Lemak (\%) & 4,02 & 3,07 & 4,00 & - \\
Kadar Air (\%) & 87,10 & 85,70 & 86,90 & - \\
Total Koloni BAL (CFU/ml) & - & $48 \times 10^{8}$ & - & Minimal $10^{7}$ \\
Total Koloni Aerob (CFU/ml) & $42 \times 10^{5}$ & $1 \times 10^{5}$ & - & - \\
BJ & 1,0272 & - & - & - \\
Laktosa & 4,70 & - & 4,90 & - \\
\hline
\end{tabular}

Keterangan: *Aritonang (2009); **Badan Standarisasi Nasional (2009)

optimum $42^{\circ} \mathrm{C}$.

Karakterisitik susu segar masih sesuai dengan referensi susu (Tabel 2). Sehingga susu segar yang digunakan untuk diolah menjadi yogurt masih layak untuk digunakan. Begitu juga untuk karakterisitk starter yang digunakan masih layak dan bagus untuk diolah menjadi produk fermentasi yogurt. Starter yang digunakan dalam pembuatan yogurt pada penelitian ini sebanyak 3\%, 5\%, 7\%. Hali ini didukung oleh Purwati et al. (2018) memberikan perlakuan penambahan starter terhadap yogurt dengan konsentrasi starter $4 \%, 5 \%, 6 \%$, dan memberikan hasil terbaik pada penambahan $5 \%$ dengan menghasilkan rasa asam dan tekstur yang baik.

\section{Bakteri Asam Laktat}

Berdasarkan uji DMRT menunjukkan adanya pengaruh yang nyata $(\mathrm{P}<0,5)$ pada pengujian jumlah total koloni bakteri asam laktat pada perlakuan perbedaan konsentrasi starter yogurt (Tabel 3). Hasil penelitian menunjukkan bahwa dengan menggunakan kombinasi bakteri Lactobacillus fermentum L23, Pedicoccus acidilactici PB22, dan Streptococcus thermophilus menghasilkan total bakteri asam laktat yang cukup banyak hingga $78,83 \times 10^{8} \mathrm{cfu} / \mathrm{ml}$. Hal ini disebabkan karena dalam proses fermentasi susu berupa yogurt diperlukan starter yang biasanya terdiri dari dua atau lebih campuran bakteri asam laktat. Kultur campuran untuk starter sangat diperlukan agar terjadi interaksi antar bakteri, tetapi akan terjadi penurunan ketika pertumbuhan BAL semakin cepat dan nutrisi semakin berkurang. Dimana pada hasil penelitian terjadi penurunan pada pemberian starter konsenterasi 7\% dengan total koloni BAL $67,67 \times 10^{8} \mathrm{cfu} / \mathrm{ml}$. Hal tersebut sesuai oleh pendapat Buckle et al. (2009) bahwa pertumbuhan bakteri akan optimal ketika jumlah nutrisi yang tersedia dalam media atau produk mendukung, ketika jumlah nutrisi dalam media berkurang maka akan terjadi kompetisi dengan mikroba lain sehingga mengakibatkan jumlah mikroba menurun. Penurunan total koloni BAL juga dipengaruhi oleh kondisi produk yang semakin asam akibat produksi asam laktat oleh BAL. Pada hasil pengujian total koloni bakteri asam laktat terbaik terdapat pada perlakuan A2 (5\%) dengan jumlah $78,83 \times 10^{8} \mathrm{cfu} / \mathrm{ml}$. Hasil penelitian ini sesuai dengan standar SNI (2009) yogurt yaitu minimal $1 \times 10^{7} \mathrm{cfu} / \mathrm{ml}$.

\section{Nilai pH}

Berdasarkan uji DMRT menunjukkan adanya pengaruh yang nyata $(\mathrm{P}<0,5)$ padanilai $\mathrm{pH}$ yogurt. Rataan nilai $\mathrm{pH}$ yogurt dengan perbedaan penambahan konsentrasi starter (Faktor A) berkisar antara 4,68 - 4,77 (Tabel $3)$. Adapun dari pengaruh penambahan starter terhadap penurunan $\mathrm{pH}$ yogurt disebabkan 
Tabel 3. Total Koloni Bakteri Asam Laktat, Nilai pH dan Total Asam Tertitrasi Yogurt

\begin{tabular}{lccc}
\hline \multirow{2}{*}{ Peubah } & \multicolumn{3}{c}{ Persentase Starter } \\
\cline { 2 - 4 } & A1 & A2 & A3 \\
\hline BAL(cfu/ml) & $47,33 \times 10^{8 b}$ & $78,83 \times 10^{8 \mathrm{a}}$ & $67,67 \times 10^{8 \mathrm{a}}$ \\
TTA & $0,640^{\mathrm{a}}$ & $0,750^{\mathrm{b}}$ & $0,740^{\mathrm{b}}$ \\
pH & $4,77^{\mathrm{a}}$ & $4,68^{\mathrm{b}}$ & $4,68^{\mathrm{b}}$ \\
\hline
\end{tabular}

Keterangan: Superskrip yang berbeda pada baris yang sama menunjukkan hasil pengaruh berbeda nyata $(\mathrm{P}<0,05)$

karena hasil metabolisme bakteri asam laktat yaitu $L$. fermentum dan $S$. Thermophillus serta Pediococcus acidilactici terbesar adalah asam laktat. Terjadinya penurunan nilai $\mathrm{pH}$ ini disebabkan semakin meningkatnya penambahan starter, karena dengan semakin tingginya penambahan starter yang maka akan semakin tinggi produksi asam laktat dan asam-asam organik lainnya, yang berpengaruh terhadap penurunan nilai $\mathrm{pH}$. Seperti yang tampak pada hasil penelitian, pada penambahan starter 5\% (A2) dan 7\% (A3), menghasilkan $\mathrm{pH}$ yogurt terendah yaitu 4,68. Hal ini didukung oleh pendapat Robinson (2002) laktosa dihidrolisa oleh enzim Beta-galaktosidase menghasilkan glukosa dan galaktosa yang hasil akhirnya adalah asam laktat. Kualitas susu fermentasi berdasarkan $\mathrm{pH}$, yang baik menurut Adriani (2005), yaitu 3,8 - 4,6. Pada hasil pengujian $\mathrm{pH}$ terbaik terdapat pada perlakuan A2 $(5 \%)$ dengan nilai $\mathrm{pH} 4,68$.

\section{Total Asam Tertitrasi (Total Titrable Acidity/ TTA)}

Berdasarkan uji DMRT menunjukkan adanya pengaruh yang nyata $(\mathrm{P}<0,5)$ pada nilai TTA yogurt. Rataan nilai TTA yogurt dengan perbedaan penambahan konsentrasi starter berkisar antara 0,64-0,75 (Tabel 3). Terjadi peningkatan TTA yogurt seiring dengan penambahan starter, disebabkan karena semakin tinggi konsentrasi starter, semakin tinggi pula aktivitas bakteri asam laktat dalam menghasilkan asam-asam organik selama fermentasi mengakibatkan terjadi peningkatkan TTA yogurt. Seperti yang terlihat pada hasil penelitian, pada penambahan starter 5\% (A2) menghasilkan TTA tertinggi yaitu 0,75. Menurut Robinson (2002), gula yaitu laktosa merupakan dasar utamapembentukan yogurt, yang secara aktif diangkut melintasi membran $S$. thermophilus melalui mediasi enzim galaktosida permease. Enzim P-galaktosidase menghidrolisis laktosa menjadi glukosa dan galaktosa. Selanjutnya glukosa dimetabolisme menjadi piruvat melalui jalur Emden-Meyerhof-Parnas (EMP) dan laktat dehydrogenase mengubah piruvat menjadi asam laktat. Hal ini juga didukung oleh pendapat Prasana et al. (2013), bahwa penurunan nilai $\mathrm{pH}$ dihubungkan dengan peningkatan TTA oleh aktivitas mikroorganisme dalam yogurt. Ditambahkan oleh Costa and Conte-Junior (2015); Costa et al. (2016), fermentasi laktosa menghasilkan asam laktat. Pada hasil pengujian TTA terbaik terdapat pada perlakuan A2 $(5 \%)$ dengan nilai TTA 0,75 .

\section{KESIMPULAN}

Dengan dilakukannya subtitusi dan penambahan bakteri asam laktat kombinasi tiga bakteri Lactobacillus fermentum, Streptococcus termophillus dan Pediococcus acidilactici PB22 sebagai starter yogurt didapatkan hasil yang memenuhi standar SNI (2009). Pada perlakuan perbedaan konsentrasi penggunaan starter terbaik terdapat pada konsentrasi 5\% dengan hasil pengujian total koloni bakteri asam laktat 78,83 x $10^{8} \mathrm{cfu} / \mathrm{ml}$, nilai pH 4,68 dan Total Asam Tertitrasi 0,75. 


\section{UCAPAN TERIMA KASIH}

Terimakasih kepada Lembaga Penelitian dan Pengabdian kepada Masyarakat (LPPM) Universitas Andalas atas Pendanaan Hibah Guru Besar klasterisasi penelitian tahun 2019. Ketua tim: Prof. drh. Hj. Endang Purwati RN, MS., Ph.D.

\section{DAFTAR PUSTAKA}

Adriani, L. 2005. Bakteri probiotik sebagai starter dan implikasi efeknya terhadap kualitas yoghurt, ekosistem saluran pencernaan danbiokimia darah mencit. Disertasi Program Pasca Sarjana. Universitas Padjajaran, Bandung.

Apriantono, A. D., N. Fardiaz., Puspitasari., Sendanawarti, dan S. Budiyantono. 2000. Analisis Pangan. Intitut Pertanian Bogor Press, Bogor.

Aritonang, S. N. 2009. Susu dan Teknologi. Swagati Press, Cirebon.

Badan Standardisasi Nasional. 2009. Standar Mutu Yoghurt (SNI-01-2981-2009). Badan Standarisasi Nasional, Jakarta.

Buckle, K. A., R. A. Edwards., G. H. Fleet, and M. Wooton. 2009. Ilmu pangan. Purnomo $\mathrm{H}$ dan Adiono, penerjemah dari food science. 13-71. UI Press, Jakarta.

Costa, M. and C. A. Conte-Junior. 2015. Chromatographic methods for the determination of carbohydrates and organic acids in foods of animal origin. Compr. Rev. FoodSci. FoodSaf. 14: 586-600.

Costa, M. P., B. S. Frasao., B. L. C. C. Lima., B. R. C. Rodrigues., C. A. Conte, and C. A. Junior. 2016. Silmutaneous analysis of carbohydrates and organic acids by HPLC-DAD-RI for monitoring goat's milk yogurts fermentation. Talanta. 152: $162-170$.

Dicagno, R., R. F. Surico., A. Paradiso., M. De Angelis., J. C. Salmon., S. Buchin.,
L. De Gara, and Gobbetti, M. 2008. Effect of autochthonous lactic acid bacteria starters on healthpromoting and sensory properties of tomato juices. International Journal of Food Microbiology. 128: 473-483.

Khikmah, N. 2015. Uji antibakteri susu fermentasi komersial pada bakteri patogen. J. Penelitian Saintek. 20(1): 45-52.

Legowo, A. M., Kusrahayu, dan S. Mulyani. 2009. Teknologi Pengolahan Susu. BP Universitas Diponegoro, Semarang.

Melia, S., E. Purwati., Yuherman., Jaswandi., S. N. Aritonang, and M. Silaen. 2017. Research Article Characterization of the Antimicrobial Activity ofLactic Acid Bacteria Isolated from Buffalo Milk in West Sumatera (Indonesia) Against Listeria monocytogenes. Pak. J. Nutr. 16: 645-650.

Messens, W. and L. De Vugst. 2002. Inhibitory substances produced by lactobacilli isolated from sourdougs- a revue. Intl. J. Food Microbiol. 72: 31-43.

Melia, S., E. Purwati., Y. F. Kurnia, and D. R. Pratama. 2019. Antimicrobial potential of Pediococcus acidilactici from Bekasam, fermentation of sepat rawa fish (Tricopodus trichopterus) from Banyuasin, South Sumatra, Indonesia. Biodiversitas. 20(12)

Purwati, E., S. Syukur, dan Z. Hidayat. 2005. Lactobacillus sp. Isolasi dari Bivicophitomega sebagai Probiotik. Proceeding Lembaga Ilmu Pengetahuan Indonesia, Jakarta.

Purwati, E., S. Melia., I. Juliyarsi., E. Rossi, dan H. Purwanto. 2018. Stok starter bakteri yoghurt Streptococcus thermophillus dan Lactobacillus ferementum dengan daya simpan 2 minggu pada suhu refrigerator. Paten no. SID201804980.

Purwati, E., D. R. Pratama., S. Melia, and H. Purwanto. 2018. Influence of Use Lactobacillus fermentumL23 and 
Streptococcus thermophilus with Dragon Fruit Extract (Hylocereus Polyrhisuz) to Quality of Microbiology, Chemistry and Organoleptic Value of Yoghurt. International Journal of Engineering \& Technology, Vol. 8, 11-Special Issue.

Pramono, Y. B., E. S. Rahayu., Suparmo, dan T. Utami. 2009. Aktivitas antagonisme bakteri asam laktat hasil isolasi fermentasi petis daging tradisional. J. Pengembangan Peternakan Tropis. 34: 22-27.

Prasana, P. H. P., A. S. Grandison, and D. Charalampopoulos. 2013. Microbiological, chemical and rheological properties of low fat set yoghurt produced withexopolysaccharide (EPS) Producing Bifidobacterium strains. FoodRes. Int. 51: 15-22.

Robinson, R. K. 2002. Dairy Microbiology Hand Book : The Microbiology of Milk and Milk Products. A Jhon Wiley and Son, Inc., Publication. USA.
Siswanti, S. W. 2002. Karakteristik fisik, kimia, dan mikrobiologi achidophilus milkplus : susu fermentasi dengan Lactobacillus acidophilus dan kombinasi dengan Lactobacillus bulgaricus atau Streptococcus thermophilus. Skripsi. Fakultas Peternakan. Institut Pertanian Bogor, Bogor.

Soeprano. 1996. Ilmu dan teknologi daging. Gadjah Mada University, Yogyakarta.

Suskovic, J., B. Kos., J. Beganovic., A. L. Pavunc., K. Habjanic, and S. Matosic. 2010. Antimicrobial activity-the most important property of probiotik and starter lactic acid bacteria. Food Technol. Biotechnol. 48(3): 296-307.

Steel, R. G. D. dan J. Torrie. 1996. Prinsip dan Prosedur Statisktik Suatu Pendekatan Biometrik. Edisi kedua. Alih Bahasa Bambang Sumantri. PT. Gramedia Pustaka Utama, Jakarta.

Yildiz, F. 2010. Development and manufacture of yoghurt and other functional dairy products. CRC Press, New York. 